\title{
Radiographic image quality after interruption of the fixing stage to view the image with a viewbox
}

\author{
Qualidade da imagem radiográfica quanto ao tempo de leitura \\ em negatoscópio com interrupção da etapa de fixação
}

\begin{abstract}
Purpose: To evaluate the quality of radiographic images with regard to the time during which the fixing stage was interrupted to allow a preliminary reading of the image in the viewbox.

Methods: Radiographs were taken with 130 Insight ${ }^{\circledR}$ periapical films, including a step-wedge and lead plate. The films were distributed into 13 groups according to the time taken for reading in a viewbox: 0 (control), 40,50,60,70,80, 90, 100, 110, 120, 130, 140 and $150 \mathrm{~s}$. During processing using the temperature-time method, the films in the experimental groups were removed $5 \mathrm{~s}$ after immersion in the fixer, placed against the light of a viewbox for the studied times and then re-immersed in the fixer to complete the fixation process. Baseplus-fog density and the densities of the first and last degree of the step-wedge were measured immediately and after six months to calculate the contrast.

Results: There were no significant differences with regard to the base-plus-fog density or the contrast values of the experimental groups when compared with the control group.

Conclusion: It was concluded that interrupting the radiograph fixation process to read the image in a viewbox does not interfere with the base-plus-fog density or with the radiographic contrast, even six months after they were taken.
\end{abstract}

Key words: Quality control; Dental Radiology; chemical process; densitometry

\section{Resumo}

Objetivo: Avaliar a qualidade da imagem radiográfica quanto ao tempo de leitura em negatoscópio com interrupção da etapa fixação.

Metodologia: Foram radiografados 130 filmes periapicais Insight ${ }^{\circledR}$ com um penetrômetro e placa de chumbo. Os filmes foram distribuídos em 13 grupos de acordo com o tempo de leitura em negatoscópio: 0 (controle), 40, 50, 60, 70, 80, 90, 100, 110, 120, 130, 140 e 150 s. Durante o processamento pelo método temperatura-tempo, nos grupos experimentais, após $5 \mathrm{~s}$ de imersão no fixador, os filmes foram removidos, postos contra a luz de um negatoscópio durante os tempos estudados e imersos no fixador para completar o processo de fixação. Foram mensuradas, imediatamente e após seis meses, as densidades base e velamento e as densidades do primeiro e último degrau do penetrômetro para o cálculo do contraste.

Resultados: Não houve diferença significativa em relação aos valores de densidade base e velamento e de contraste das radiografias dos grupos experimentais comparando-os com o grupo controle.

Conclusão: Concluiu-se que, durante o processamento das radiografias, os tempos de leitura em negatoscópio não interferiram na densidade base e velamento, nem no contraste radiográfico, mesmo após seis meses de seu arquivamento.

Palavras-chave: Controle de qualidade; radiografia dentária; processamento químico; densitomeria

\section{Anna Débora Araújo Lourenço ${ }^{a}$ \\ Andréa dos Anjos Pontual b \\ Márcia Maria Fonseca da Silveirac \\ Maria Luíza dos Anjos Pontuald}

\begin{abstract}
a Department of Clinic and Social Dentistry, School of Dentistry, Federal University of Paraíba, João Pessoa, PB, Brazil

${ }^{b}$ Department of Oral Diagnosis, School of Dentistry, Pernambuco University-UPE, Camaragibe, PE, Brazil

c Semiology Course, School of Dentistry, Pernambuco University-UPE

d Department of Clinic and Social Dentistry, School of Dentistry, Federal University of Paraíba, João Pessoa, PB, Brazil
\end{abstract}




\section{Introduction}

The radiographic exam is widely used in dentistry and is a highly relevant complementary exam (1). Radiographic diagnosis complements the clinical examination and helps to resolve diagnostic doubts, allowing the professional to plan treatment more safely; radiographs can also be used in follow-ups and as documentation (2). Radiographic images are important for the diagnosis of pathologies and anomalies in addition to confirming the integrity of hard tissues in the mouth, and radiography is often the only means to detect any alteration that may be present (3). For this purpose, the radiographic technique needs to follow a strict sequence of stages that begin with the correct exposure and end with final drying (4).

Radiographic processing is the general term used to describe the sequence of events required to convert the latent image contained in the sensitized emulsion of the radiographic film into a real and permanent radiographic image (5). Radiographic processing consists of chemical treatment of the film (6) that enables the permanence of the image on the film so that it can be adequately interpreted (7). This processing must be performed under controlled and standardized conditions, with redoubled attention to details (5).

Some areas in dentistry, such as oral surgery and endodontics, require radiographs as soon as possible, and for this reason, many stages of the correct radiographic processing are neglected, particularly regarding film fixation (7). It is not unusual to see professionals taking the radiographic film out of the fixer solution before the fixation process is completed, and taking the radiograph to the viewbox for interpretation. This procedure may cause an alteration of the diagnostic validity of the radiograph immediately or a certain time after it has been taken, compromising the legal value of the radiograph image. Furthermore, poor quality of a radiograph may require the dental professional to obtain a new radiograph, resulting in unnecessary exposure of the patient (8).
The literature on this topic is scarce. Araújo et al. (9) studied the influence of variations of the fixation process on the quality of the image. The authors verified that a 30-s interruption in the fixing process of radiographs after fixing had been in progress for $5,10,20,30,40,50$ and $60 \mathrm{~s} \mathrm{did}$ not interfere with the base-plus-fog density or the contrast of the radiograph.

Therefore, the aim of this study was to evaluate the quality of the radiographic image with regard to the amount of time spent observing the radiograph after $5 \mathrm{~s}$ of initial fixation. The quality was assessed both immediately and after six months.

\section{Methodology}

A total of 130 Insight $^{\circledR}$ periapical films were used, with sensitivity E/F, size 2 (Eastman Kodak Company, Rochester, USA), within the period of validity. The films were exposed by using a 70X dental X-ray appliance with total filtration equivalent to $2.5 \mathrm{~mm}$ of aluminum (Dabi Atlante, São Paulo, Brazil) operating at $70 \mathrm{kVp}$ and $8 \mathrm{~mA}$. For these exposures, a standardizing device was used to allow a constant perpendicular incidence of the X-ray beams on the film and on the objects to be radiographed, in addition to maintaining a constant focus-film distance of $30 \mathrm{~cm}$.

First, the exposure time was selected, in which an aluminum density scale with 10 degrees (Fig. 1) and each degree had 2-mm thick increments and were radiographed with exposure times of $0.2,0.3,0.4,0.5,0.6,0.7,0.8,0.9$ and $1.0 \mathrm{~s}$. After these exposures, radiographic processing was performed manually using the temperature-time method. The films were processed individually and in a completely opaque portable dark chamber (Del Grandi, Ribeirão Preto, São Paulo, Brazil) using solutions ready for use (Kodak, Eastman, Rochester, USA), a chronometer and an immersion thermometer. At the time of processing, the solutions were at a temperature of $25^{\circ} \mathrm{C}$, and based on the table provided by the film manufacturer, film immersion times in the developer and in the fixer were 3 and $4 \mathrm{~min}$, respectively.
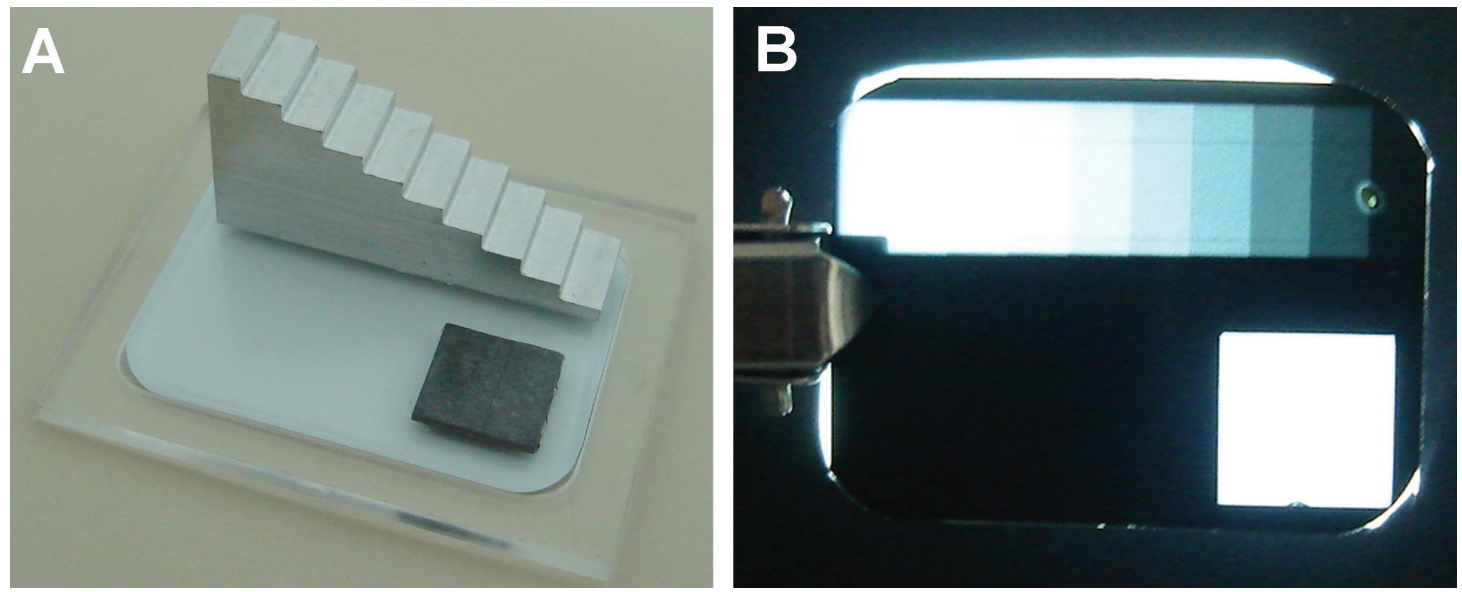

Fig. 1. (A) Density scale and lead plate positioned on the radiographic film for exposure. (B) Radiograph exposed to the viewbox light with mask. 
The degree of image density corresponding to the fifth degree of the radiographed scale was measured by means of a densitometer (MRA, São Paulo, Brazil). The time selected was that at which the radiograph obtained the image density closest to 1 , with the time $0.7 \mathrm{~s}$ being chosen.

After selecting the exposure time, radiographs of the density scale and a lead plate were taken with 130 films, under the same standardized conditions described above. After this, the radiographic films were randomly divided into equal groups according to time in which they would remain out of the fixer after initial fixation of $5 \mathrm{~s}$, these times being 40,50 , $60,70,80,90,100,110,120,130,140$ and 150 s out of the fixer. In the control group, the radiographs remained in the solution during fixation. Therefore, a total of 13 groups were assessed, including 12 experimental groups and 1 control group.

Radiographic processing of the 130 films occurred in a standardized manner as described above in the selection of the exposure time. The radiographic films of the control group were processed without interrupting the fixing process. In the other groups, after intermediate washing, the films were immersed in the fixing solution for $5 \mathrm{~s}$, removed from the fixer and placed against the light of a 600 lux viewbox (Miolight, São Paulo, Brazil) with a mask. According to the group they belonged to, they remained out the fixer for 40 , $50,60,70,80,90,100,110,120,130,140$ or 150 s (Fig. 2), respectively.

After the interruption in the fixing process, the films were again immersed in the fixer to complete the 4-min fixation process. It is important to emphasize that the solutions used were changed after each group was processed to avoid the interference of other factors related to the processing solutions and also to enable the groups to have similar assessment conditions.

Immediately after obtaining the radiographic images and after a period of six months, the optical densities of the $2-\mathrm{mm}$ and 20-mm steps and the base-plus-fog density were measured by means of a digital densitometer (MRA, Ribeirão Preto, SP, Brazil). According to the optical densities obtained, the radiographic contrast of each film was calculated by using the following formula according to Price's methodo$\operatorname{logy}(10)$ :

$$
\mathrm{C}=\left(\mathrm{D}_{2}-\mathrm{D}_{1}^{1 / 2}\right) /\left(\mathrm{D}_{2}+\mathrm{D}_{1}\right)
$$

where $\mathrm{D}_{2}$ corresponds to the density of the densest area ( $2 \mathrm{~mm}$ step) and $D_{1}$ is equivalent to the least dense area (20 mm step) (10).

Once the contrast and the base-plus-fog density values of the radiographs were obtained for each group, they were tabulated in the program Microsoft Office Excel 2003 and submitted to statistical analysis at a level of significance of 0.05 , using Minitab 14 and Stata 9.2 software. The data were summarized by the usual measures of location and dispersion. Variation of base-plus-fog density and radiographic contrast values among the groups (identified according to time of reading the radiographs in the viewbox) were assessed by the adjustment of a linear regression model. The intensity of the linear association between the viewbox time and density or contrast was assessed by Pearson's correlation coefficient.

\section{Results}

Figure 2 shows the mean distribution and standard deviation of the base-plus-fog density values according to the viewbox observation times studied. There was no significant variation in relation to the time the radiograph was exposed to light in the viewbox immediately after $5 \mathrm{~s}$ of fixation $(P=0.273)$. After the radiographs had been filed for six months, there was no significant variation among the base-plus-fog density means of the groups of radiographs studied $(P=0.414)$ (Fig. 2B).

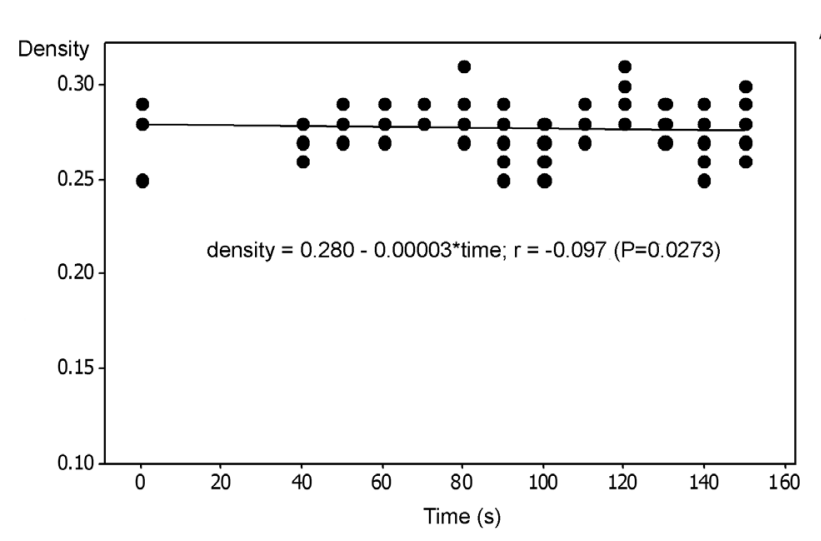

A

B

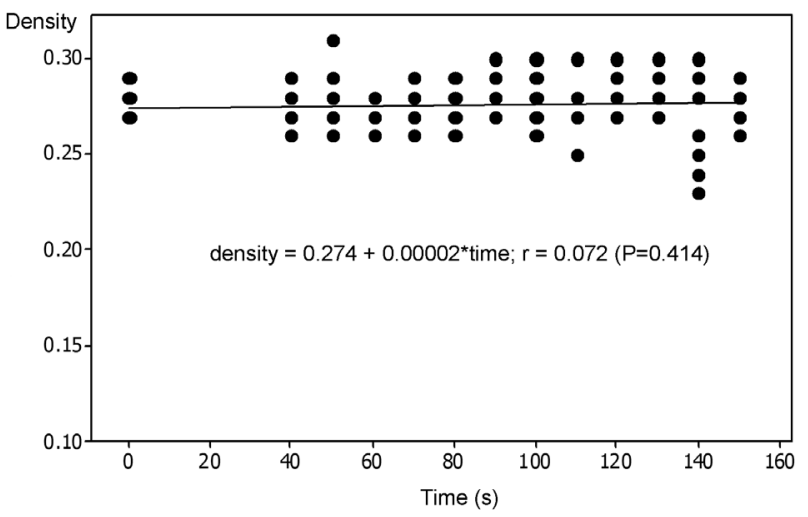

Fig. 2. Mean and standard deviation of the base-plus-fog density values: $(A)$ immediately after the radiographic processing of the films; (B) after six months of filing.

Figure 3A shows the radiographic contrast values measured immediately after processing the films. There was no evidence to reject the hypothesis that the contrast values were stable during the interval of observation time $(P=0.137)$. Figure $3 \mathrm{~B}$ shows the distribution of contrast values of the studied groups after the radiographs had been filed for six months. Although the slope of the adjusted straight line was negative, the association with the observation time was not significant $(P=0.262)$. 

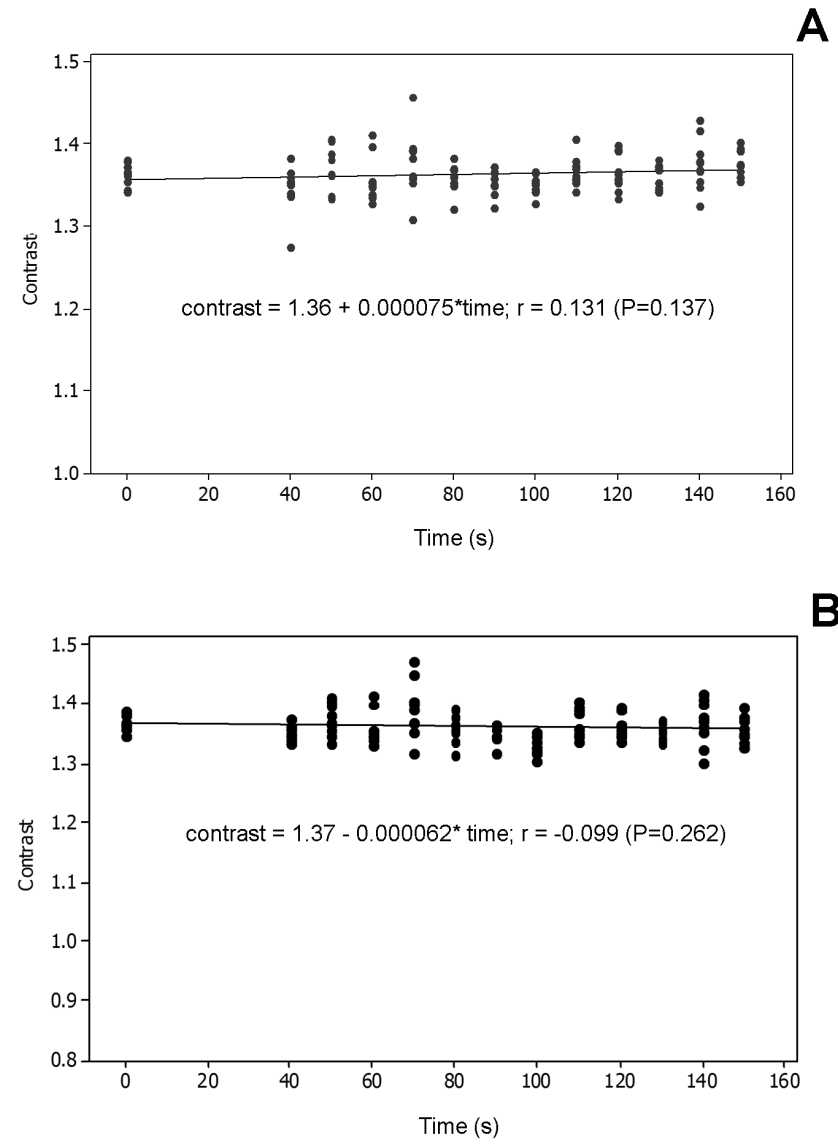

Fig. 3. Mean and standard deviation of the contrast values: (A) immediately after the radiographic processing of the films; (B) after six months the films were filed.

\section{Discussion}

A radiograph image of good quality should display the maximum amount of detail, moderate contrast and density, and minimal distortion (11-13). All the steps involved in obtaining a radiographic image must be followed carefully. Although radiographic processing is considered an easy step, it is responsible for a great number of radiographic failures $(3,13)$. Not only are errors resulting from this step the most frequent, but they are also the easiest to avoid (14). Previous studies have shown that radiographic failures may result in incorrect diagnoses, repetition of exams, additional costs, waste of time and an increase in the dose of ionizing radiation delivered to the patient $(8,13,15)$. Therefore, it is important to have quality control to avoid these failures (16) and, consequently, unnecessary repetitions (12).

One should comply with all of the manufacturer's technical recommendations regarding the film immersion time in the processing solutions (17). There still is controversy about the adequate time during which the radiographic film should be kept immersed in the fixing solution. This time must correspond to twice the amount of time required for the milky image to become transparent, which occurs in around 8 to $10 \mathrm{~min}(5,12)$. However, according to the radiographic film manufacturer, immersion from 2 to 4 min in the fixing solution is recommended.

The type of analysis made by means of the film densities is denominated objective analysis (18). Base-plus-fog density is represented by the optical density inherent to the radiographic film offered by the manufacturer (18). In this study, the baseplus-fog density values ranged from 0.25 to 0.31 , which were higher values than those found by other authors $(11,19,20)$. This discrepancy can be explained by the different conditions under which the films were processed. However, they are within the range of values considered acceptable for the base-plus-fog densities of intra-oral radiographic films (21), and they are within the range recommended by ISO 3665 (maximum of 0.35 ) for films with sensitivity E/F (22).

B

Radiographic contrast represents the differences between the several degrees of black, white and gray of the radiographic film; that is, it consists of the differences between radiographic densities of the different regions of a radiograph (5). In this study, the calculation of the radiographic contrast of each film followed Price's study method (10).

Moreover, with respect to radiographic contrast, in the present study the values ranged from 1.28 to 1.47. Studies assessing films with E sensitivity (Flow and Ektaspeed Plus), processed according to the specifications of the ADA, found contrast values of 1.88 and 1.75, which are much higher values than those of 1.5 required by ADA (23). The mean contrast value was 1.36 , below the value established by the ADA, but much closer to this value.

Araujo et al. (9) verified that interrupting the fixing process after $5 \mathrm{~s}$ of immersion in the fixing solution and reading the radiograph in the viewbox for $30 \mathrm{~s}$ did not interfere objectively with the quality of the radiographic image. In the present study, using a similar methodology (9), we objectively evaluated the influence of viewbox observation times $40 \mathrm{~s}$ or greater after initial fixing for $5 \mathrm{~s}$. Furthermore, the influence of these factors was investigated after the radiographs had been filed for six months. The observation time in the viewbox after initial fixing of $5 \mathrm{~s}$ had no influence, even after the radiograph had been filed for six months because the base-plus-fog density and radiographic contrast of the radiographs of the experimental groups did not vary significantly compared with those of the control group. These results suggest that there are two factors are involved and they are as follows: first, the permanence of the fixing solution on the radiographic film during the reading period in the viewbox and second, the importance of the fixing process being completed, even after initial fixation of $5 \mathrm{~s}$. With regard to the first factor, the permanence of the fixer on the radiograph during the reading period in the viewbox allows continuity of action of the sodium hyposulfite in removing the silver grains.

Therefore, it is possible to interpret radiograph processing before the fixing process has been completed without reducing the quality of the radiographic image, provided that the film is not washed before reading in the viewbox, observation is less than 2.5 minutes and after reading, the radiographic film is returned to the fixer to complete the fixing process. 


\section{Conclusions}

According to the experimental conditions in this study, it was concluded that the viewbox observation time, which interrupts the fixation stage of the radiographic processing, does not interfere with the base-plus-fog density or contrast of the radiographic image either immediately after it is obtained or after the radiographs have been filed for six months.

\section{References}

1. Whaites E. Princípios da radiologia odontológica. 3. ed. São Paulo: Artmed; 2003.

2. Kreich EM, Querioz MGS, Sloniak MC. Controle de qualidade de radiografias periapicais obtidas no curso de Odontologia da UEPG. Biol Health Sci 2002;8:33-45.

3. Gasparini D, Vaz EMS, Haiter Neto F, Boscolo FN. Análise de erros radiográficos cometidos por alunos da Faculdade de Odontologia de Piracicaba, no período de 1975 a 1988. Rev Odontol Univ São Paulo 1992;6:107-14.

4. Capelozza AL, Álvares LC. Estudo comparativo entre os filmes radiográficos dentais AGFA-GEVAERT, KODAK ULTRA-SPEED e KODAK EKTASPEED, processados na solução Sillib. Rev Odontol Univ São Paulo 1990;4:92-6.

5. Tavano O, Estevam E. A imagem radiográfica. In: Alvares LC, Tavano O. Curso de radiologia em odontologia. 4. ed. São Paulo: Ed Santos; 1998.

6. Freitas L. Fatores na produção da imagem radiográfica. In: Freitas A, Rosa JE, Souza IF. Radiologia Odontológica. 6. ed. São Paulo: Artes Médica; 2004.

7. Greco AC, Lima FA, Gorgoni SR, Silva JBA, Manzi FR. Efeito da diminuição do tempo de lavagem final ou sua ausência na qualidade da imagem radiográfica. Rev ABRO 2006;7:5-9.

8. Goren AD, Lundeen RC, Deahl ST, Hashimoto K, Kappa SF, Katz $\mathrm{JO}$, et al. Updated quality assurance self-assessment exercise in intraoral and panoramic radiography. American Academy of Oral and Maxillofacial Radiology, Radiology Practice Committee. Oral Surg Oral Med Oral Pathol Oral Radiol Endod 2000;89: 369-74.

9. Araujo AMM, Pontual AA, Silveira MMF, Brasileira IV, Pontual MLA. Análise objetiva da qualidade da imagem radiográfica quanto à interrupção do processo de fixação. Rev Assoc Paul Cir Dent 2009;63:394-8.

10. Price $C$. The effects of bean quality and optical density on image quality in dental radiography. Oral Surg Oral Med Oral Pathol Oral Radiol Endod 1986;62:580-8.

11. Dezotti MSG. Avaliação de filmes radiográficos periapicais em diferentes condições de processamento pelo método sensitométrico, digital e morfométrico. [thesis]. Bauru (SP): Faculdade de Odontologia de Bauru, Universidade de São Paulo; 2003.

12. Langland $\mathrm{OE}$, Langlais RP. Princípios de diagnóstico por imagem em odontologia. São Paulo: Santos; 2002.

13. Pontual ML, Veloso HHP, Pontual AA, Silveira MMF. Errores en radiografias intrabucales realizadas en la Facultad de Odontología de Pernambuco-Brasil. Acta Odontol Venez 2005;43:19-24.

14. França KP, Pontual AA, Salazar-Silva JR, Pontual MLA, Formiga Filho AL. Influência da região radiografada e da fase de tratamento endodôntico na qualidade de radiografias periapicais. Pesqui Bras Odontopediatria Clin Integr 2008;8:105-105.

15. Zenóbio MAF, Silva TA. Proteção radiológica em clínicas radiológicas. Rev ABRO 2003;4:35-9.

16. Brücker MR, Tavano O, Costa NP. Análise do comportamento das soluções RPXOmat da Kodak através do método sensitométrico. Rev Odonto Ciênc 1992;7:37-52.

17. Lascala CA, Mosca RC. Filmes e Processamento Radiográfico. In: Panella J. Radiologia Odontológica e Imaginologia. Rio de Janeiro: Guanabara Koogan; 2006.

18. Damian MF. Efeito de um banho de álcool do tempo de secagem de radiografias e suas conseqüências no arquivamento. [dissertation]. Piracicaba (SP): Faculdade de Odontologia de Piracicaba, Universidade Estadual de Campinas; 2001.

19. Ludlow JB, Platin E; Mol, A. Characteristic of Kodak Insight, an F-speed intraoral film. Oral Surg Oral Med Oral Pathol Oral Radiol Endod 2001;91:120-9.

20. Syriopoulus K, Velders XL, Sanderink GCH, van Ginkel FC, van der Stelt FC. Sensitometric and clinical evaluation of a news F-speed dental X-ray film. Dentomaxillofac Radiol 2001;30:40-4.

21. White SC, Pharoah MJ. Oral radiology: principles and interpretation. 5. ed. Saint Louis: Ed Elsevier; 2004.

22. International Organization for Standardization. International Standard ISO 3665. Photography - Intraoral dental radiographic film -Specification. 2. ed. Geneve: ISO; 1996.

23. White SC, Yoon DC. Comparison of sensitometric and diagnostic performance of two films. Compend Contin Educ Dent 2000; $21: 530-9$ 